\title{
Developer obligations - land for public purposes in selected countries
}

\author{
Tomasz Ossowicz \\ tomasz.ossowicz@pwr.edu.pl \\ Wydziat Architektury, Politechnika Wrocławska
}

\begin{abstract}
Paper presents a comparison of instruments to oblige developers to free transfer land for public infrastructure in Canada, USA, Australia, Germany, and Poland in following dimensions: form, procedure, and an extent of obligations, documents defining obligations, public objects included in obligations, and utilization of exacted land. Compared instruments were evaluated according to their: simplicity, operability, and transparency as well as their role for creation of high quality urban tissue, equality of developers before the law, and complexity of urban transformations.
\end{abstract}

Key words: operational urban planning, land for public purposes, land value capture, indirect developer obligations.

\section{Introduction}

In creation of spatial arrangements a key role is played by a field of knowledge called operational planning. It can be defined concisely as an art of implementation of planning visions or concepts. According to Charter of European Planning [2013] planner committed to this kind of activity is engaged as a manager of cities and regions. Without operational planning the best visions remain only on paper or in virtual files. It is also important that an urban vision is dependent highly on instruments applied for its implementation. We can say that operational planning for urban planning is the same as engineering for architecture. An architectural design is highly dependent on chosen building technique.

In this field a substantial matter is a way of exaction land for public infrastructure, among others for: roads, streets, technical systems, schools, kindergartens, green areas or recreation facilities. In Poland it is a task of public institutions of various levels including municipalities. National regulations provide legal instruments for acquisition necessary land of diverse level of effectiveness. However, independently on kind of object of public infrastructure application of these instruments is financed by public sector in almost all cases. Does it go this way everywhere and always? Are in other countries different sources to cover costs of acquisition land for public purposes? These questions are more and more crucial considering tremendous development boom in Poland. Observing underinvestment of public infrastructure on areas of dynamic real estate development one can conclude that current needs overrun financial capacities of municipalities. In this situation it would be better to be prepared for crisis of municipal finances and to consider counter-measures. It should be stressed that a lack of legal or financial capability to acquire land for public purposes can be serious barrier to create a spatial order. For instance in such a situation insufficient street network may be planned or streets may be located not in places, where they are necessary.

In terminology of land value capture (LVC) by public sector the notion "indirect developer obligations" is frequently used [Altermann, 2010; Muñoz Gielen, von Krabben, 2017]. It is understood as a full or partial contribution of a potential developer or an owner (also perpetual user) considered as a potential developer to necessary actions in public sphere involved by his development. It is mainly financing of public infrastructure needed for service developed objects. In many countries free exaction of land for public purposes or payments for this land emption are also included in indirect developer obligation. 
This paper presents short comparison ways of free land exaction or financed its emption with not municipal sources. Except Poland, four countries are chosen for comparison, where instruments of indirect developer obligations are relatively well developed. They are: Canada (Province of Alberta), USA (State of Washington), Australia (State of Victoria) and Germany.

Six aspects are taken into account in the comparison:

1. Form of obligations: transfer of land or payment.

2. Procedure of realization of obligations.

3. Planning documents being legal base for obligations.

4. Elements of public infrastructure included in obligations.

5. Extent of obligations.

6. Way of utilization of exacted land or collected payments.

\section{Comparisons}

\section{Form of obligations}

In Canada, USA and Germany owners and perpetual users of properties in case of development are obliged to transfer land free for public purposes. In comparison it has to be seen differences in development "customs" in these countries. In first two developer buy land in to create land stock suitable for planned development, taking into account that its part will be used for public purposes. For example, if he is going to construct housing estate, he has to have enough land also for public streets, schools and parks. In Germany lots for development is not created by developer, but municipality by land readjustment (Baulandumlegung). Within this procedure it acquires for free land for public purposes. Owners plays much more passive roles than in North American countries being compared. They do not need to create terrains for development themselves, because even lots with the most strange shapes are exchanged into regular building plots as an effect of land readjustment.

In USA developer instead a transfer of land may give municipality free easement on his land [RCW, 58.17.218]. In Canada it is also possible, but only for land with natural values which has to keep its character (environmental reserve easement) [Municipal... 2017, sect. 664-2]. Moreover Canada allows for payment instead transfer of land [Municipal... 2017, sect. 661-b].

In Australia, Canada and USA developers are charged for public infrastructure needful to service for developed objects (in Australia standard and supplementary infrastructure levies [Planning 2017, section 46GD], in Canada off-site levies [Municipal 2017, section 648], in USA impact levies [RCW, 82.02.050]). Collected funds are used among others for purchase land for public purposes.

In Poland on the formally appointed revitalization areas a condition for building permit may be required planning agreement where developer commit himself to construct on his cost defined elements of public infrastructure and to transfer it with land under it to municipality [art. 37i, uopizp]. Although no municipality has applied this instrument yet ${ }^{1}$, however it should be taken under consideration, because in future it may be used on other places than areas of revitalization, where seemingly it could be more needed. Similar agreements are also in Australia permissible, but in exchange of alike developer obligations municipal council promises amendment of land-use and planning requirements in binding planning documents.

\section{Procedure of realization of obligations}

In USA and Canada a transfer of land is connected with decision on subdivision of property. The subdivision procedure in these countries is much more complicated than in Poland. In course of it a subdivision map is elaborated, which is largely local development plan. It contains layout of building plots, system of streets, technical infrastructure and drainage, areas for public facilities, greenery, and for some commercial services, e.g. shopping,

1 No one from three municipalities - Bytom, Łódź, and Wałbrzych, which have government support for revitalization as a pilotage implementation of regulations introduced in Act on Revitalization [uor, 2015] is going to adopt local plan of revitalization. 
as well as set-back lines ${ }^{2}$. Usually financial analyses are attached, which presents forecasted plot values. They are used in preparation for mortgage as well as for public help for development, e. g. in USA by insurance of credit by Federal Housing Administration. All this matters must be consulted with many municipal departments.

In USA and Canada a practice of urban agreements is more and more widespread. In these agreements municipality guarantees permanence of land-use and requirements for developments, while developer or landowner declares obligations for public sector in case of development, including free transfer of land for public purposes. These kind of agreements ensures predictability of actions and attitudes both sides, but it is not fully sure, if they are consistent with Constitution of USA. In American legal system it will be clear, where it becomes matter of deliberations for Supreme Court resulted carved in stone legal precedent. Land dedication in USA, although it may be a condition for acceptation of development is treated as an donation, then donor has certain honorary rights ${ }^{3}$.

In Germany land acquisition is resulted from land readjustment (Baulandumlegung) realized almost always after legally binding land-use plan (Bebauungsplan) comes into effect. All properties taken to land readjustment is joined together into one mass. Next, areas necessary for public infrastructure are divided from this mass, and acquired by appropriate public institutions. The rest is subdivided into building plots for development according to land-uses determined in legally binding land-use plan, which are allotted for owners of properties being input to the mass, proportionately to its area or to its property values. Polish municipalities have at their disposal similar instrument, but they must financially compensate for acquired land, and resulted plots can be allotted only by area. In both countries owners and perpetual users can be charged with levies based on increase of value (In Poland optaty adiacenckie), while in Germany they can be imposed as an alternative of free land exaction. The rate of levies in Poland cannot excess 50 per cent [BauGB, uogn]. Seemingly authors of Polish regulations assumed that municipality has to pay for land for public purposes, but get its own back collecting high levies. In Germany they probably supposed that sometimes it is better not to pay for land and after not to compensate by levies, while level of probable refund is not predictable. Moreover, in Germany, where almost no development is allowed without legally binding land-use plan, and after its coming in force municipality obligatory constructs public infrastructure, the result of this plan adoption is very high increase of land value, which becomes yet higher after land readjustment.

In Australia a condition required for building permit is to pay standard and supplementary levies or to conclude agreement on its payment in instalments with agency specially created to collect these levies. Instead levies developer may covenant for defined construction works [Planning... 2017, section 46GD, 46N, and 46O].

Polish and Australian urban agreements between developer and municipality has different characters. Polish ones, as a condition for building permit, documents technical specification and a date of realization necessary building works by developer and a date of free transfer to municipality completed public objects or facilities, included land under them [art. 37i ust. 5, uopizp]. Urban agreements in Australian version are fully voluntary for both sides. In exchange of developer obligations municipal council promises amendment in planning scheme - the key planning document being basis for planning permits [Planning... 1987, sections 173-176]. From countries being compared only Australia allows this kind of agreements: obligation for public sector in return amendment in local law. It is legal due to that, a public party concluding agreement is not a mayor but legislative body - municipal council ${ }^{4}$. This is a fundamental difference between Australian legal system, and Polish one, in which legislation cannot be subject of agreement with individual company. It is as if a national parliament conclude a contract with producer of steel for exemption from tax in return of free delivery of iron reinforcing bars for motorway construction. Australian very practical approach not keeping off such solutions, seemingly allows for more flexibility, but requires stronger protection against potential corruption.

2 In Canada the procedure of subdivision is no required for properties with area 0,8 ha or less as well as if a result of subdivision are agricultural plots bigger than 16 ha each [section 663, Municipal...].

3 E.g.in State of Washington, if developer dedicates land with area less than 2 acres for public park, he has a right to designate that the park be named in honor of a deceased individual of good character [RCW 58.17.110-3].

4 In Australia also planning permits are issued by municipal council. 


\section{Planning documents being legal basis for obligations}

Except Germany, in all countries being compared developer obligation to transfer of land free for public purposes or to pay levies for land acquisition are determined in municipal planning documents. Canadian "municipal development plan" defines maximal levels of land contribution, which may be required [Municipal 2017, sections 661, and 666]. In USA rules of designation land for public purposes are determined in "subdivision ordinance" or in "zoning ordinance", which are in many municipalities connected in one entity. In both countries land-use plans may determine areas for public purposes. In Australia "infrastructure contribution plans" $(I C P)^{5}$ are elaborated. They determine levels of two types of levies for public infrastructure including for land acquisition - "standard" ones and dependent on specific features of place "supplementary" ones. ICP is introduced as amendment thematic layer of the most important municipal planning document - "planning scheme" [Planning... 2017, sections 46GB, and 46GD]. In Poland developer obligations required for building permission on revitalisation area are formulated in legally binding "local plan of revitalization". In Germany conditions for land readjustment are defined in legally binding land-use plan (Bebauungsplan). But the procedure is described in Building Code (BauGB, §45-84).

\section{Elements of public infrastructure included in obligations}

In all countries in comparison land may be acquired as well for street, roads and technical infrastructure as for parks, green areas and recreational facilities of various character. Everywhere except Germany developers may be obliged to transfer land free or to pay levies used to acquire land for various public facilities, among others: schools, kindergartens, nurseries, day care centers for mothers and children, seniors, libraries and other cultural and sport facilities, but in Canada also for police and fire brigade stations.

In Germany in procedure of land readjustment areas for facilities of these kinds are not taken from the mass of land, may be because relatively small size of areas comprised by these processes. In Canada developer can be obliged to transfer land free for affordable housing, Also on revitalization areas in Poland similar requirement may be imposed, only not a land has to be transferred but ready dwellings, whereby regulation do not indicate for who they should be addressed. The same matter is regulated differently in USA. There developer may be charged with "impact fee" for realization public purposes, included construction of low-income housing. Developer may be exempted from this fee in exchange of covenant that, prohibits using his property for any purpose other than for low-income housing, while the covenant must define dwelling price constraints and household income limits for the low-income housing [RCW 82.02.060]. Frequent usage of this instrument resulted with many groupings of buildings with dwellings addressed to less wealthy Americans within housing estates.

In Canada "environmental reserve" is separated. It consists of free transferred land of a swamp, gully, ravine, coulee or natural drainage course, land unstable, and that is subject to flooding, as well as minimum 6 meters wide strips of shores of lakes, rivers, streams or other bodies of water, which allows to prevent pollution and to provide public access. Environmental reserve must be left in natural state or used for public park [Municipal 2017, section 664]. In Germany in real readjustment land necessary for protection against harmful environmental conditions and for purification and overflow basins for rainwater as well as for counterbalancing negative effects for environment and landscape resulted from permission for developments [§55, BauGB].

\section{Extent of obligations}

In Germany area of land designated for public purposes within land readjustment cannot exceed 30 per cent of area of a property input to the procedure, if it was not serviced with public infrastructure before, and 10 per cent in other case. Also Canadian law limits area of land, which may be required to transfer for roads and technical infrastructure to 30 per cent of an area of land being subdivided diminished by an area of environmental reserve, but an area of so-called "municipal and school reserve" is limited to 10 per cent, however while 
density is higher than 30 dwellings per hectare - to 15 per cent. In consequence, if environmental reserve takes e.g. 20 per cent of area of land being subdivided, developer will be obliged to transfer free even 56 per cent of his land to municipality.

In Australia regulations restrict level of infrastructural levies in respect to floor space or cost of erected objects $^{6}$. There are no state or federal restrictions in USA of area or value of land which dedication may be a condition for acceptation of land subdivision. However in each individual case planning authority is obliged to prove, how much public land and where is necessary for efficient functioning of emerging urban entity. On Polish revitalization areas required developer contribution cannot exceed increase of property value resulted from adoption or amendment of local plan of revitalization.

\section{Way of utilization of exacted land or collected payments.}

In Canada as well as in USA land transferred by developers to municipality, and in Australia land purchased by municipality partially using funds collected from infrastructural levies, is place for construction of objects of public infrastructure by public institution according to their competence or by developers [Municipal... 2017, sections 671-677]. In first case the source of financing are predominantly payments from developers: in Canada "off-site levies" and "redevelopment levies" [Municipal... 2017, sections 648, and 647], in USA "impact fees" [RCW 82.02.050] , and in Australia "standard" and "supplementary infrastructure levies" [Planning... 2017, section $46 \mathrm{GD}$ ]. In second case developers are obliged to finance developments of public purpose themselves on basis of agreement with municipality: in Canada "on-site servicing agreement" [Municipal... 2017, sections 650-651], in USA "development agreement" [RCW 36.70B.170], in Australia "voluntary planning agreement"

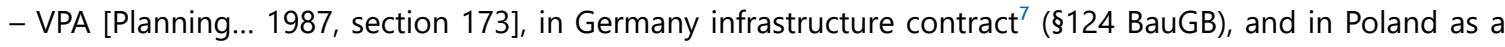
public private partnership.

\section{Conclusions}

Let us evaluate instruments being used in compared countries. Let us consider, which ones gives the biggest chances for high quality of urban arrangement. Results of comparison indicate clearly German system.

Either on land with dense division into small and strange shape properties in hands of numerous owners or on big not divided areas in one hand, planners have a big chance for creation of harmonious urban tissue matching to planned land-uses and landscape. Moreover possibility of free acquisition of land for public purposes is a great incentive for municipalities to implement it. American, Canadian, and Australian tools allow to achieve similar results usually, when developer have collected sufficiently big set of land properties to have space for creation regular urban entity. Their strength is an avenue to acquire land for more elements of public infrastructure than in Germany. As a weakness may be considered that, an initiatives of urban entity creation, in contradictory to German approach, are left in private hands. Therefore more efforts are needed for current coordination of urban development processes. Polish solution does not give immediate effects in quality of spatial arrangements but creates chance for better coordination of revitalization processes.

Important feature of instruments of operational planning is its simplicity and operability as well as transparency and respect for equality of developers before the law. In these measures Australian tools seem to be the simplest. Infrastructure contribution plans (ICP) expressly determine requirements amount of infrastructural levies. Nevertheless prescribing obligation for public sphere on developers by municipal council is completely discretionary, then neither transparent and predictable for potentially charged, nor operable, because each case must be analyzed very individually. Yet it is not easily to keep equal approach to all developers. By these criteria Polish revitalization instrument can be assessed positively, because required obligation of potential developer has to be determined in legally binding plan and thus predictable. Practice will show, if municipalities manage

6 E.g.: for housing it cannot be higher than $\$ 900$ (Australian dollars) per each dwelling and 0,25 cent per each dollar in the cost of construction of any other kind of building.

7 Erschließungspflicht nach abgelehntem Vertragsangebot. 
effectively with equal approach to owners of various properties covered by local plan of revitalization. In principle a "safe" solution would be charging all with the same per cent of land value increase. Also principles of land readjustment in Germany are transparent and simple. The extent of land for public purposes are decided in legally binding land-use plan (Bebauungsplan). Next position is occupied by Canada, where planning documents define expressly maximal percentage of share of land to be transferred free to municipality, however closing decision is issued after individually proceeded property subdivision supported by analysis performed by municipal services. The least transparent and labor-consuming are American procedures. Requirements for extent of land to transfer and participation in public investments are carefully analyzed in each individual case, and the law does not impose any restrictions on it. These rational nexus for these requirements are derived and introduced to planning documents with respect to the principle "the straw that breaks the camel's back" and judicial precedents.

The last criterion is a role of instruments being applied in reinforcing of urban project complexity. In this sphere no one from described is fully effective. At this aspect American and Canadian approach should be evaluated highly due to much space for urban agreements allowing for coordination of private and public developments in relation to transfer developer's land to municipality. Moreover acceptable extent of this transfer is established on high level. Australian "voluntary planning agreements" (VPA) go further, because they allow make arrangements on amendment in regulations, but in principle do not touch transfer of land. In all these countries agreements are concluded only with one developer in contradistinction to e. g. French instrument "zone of concerted development" (zone d'amanagement concerte) or discussed in Poland but never introduced "areas of integrated development" (obszary zintegrowanych inwestycji - OZI).

In this paper only some kinds of instruments of operational planning connected with one matter and from limited number of countries are deliberated. Facing as well dynamic growth in Poland as permanent improving instrumentation in urban planning on the world this kind research should be conducted in a wide scope.

\section{References}

[1] Alterman R., 2012. Land use regulations and property values: The "Windfalls Capture" Idea Revisited, Pre-publication version of: Chapter 33, w: The Oxford Handbook on Urban Economics and Planning. Edited by Nancy Brooks, Kieran Donanghy and Gerrit-Jan Knapp. Oxford University Press. 755-786

[2] The Charter of European Planning. The Vision for Cities and Regions - Territoires of Europe in the $21^{\text {st }}$ Century. ECTP-CEU (The European Council of Spatial Planners - le Conseil Europeeén des Urbanistes). Barcelona 2013.

[3] Cullingworth B., Caves W., 2003. Planning in the USA. $2^{\text {nd }}$ ed. London, New York, Routledge.

[4] Gallion A. B., Eisner S., 1985. The Urban Pattern. City Planning and Design. New York, Van Nostrand Reinhold Company.

[5] Lorens P., Martyniuk-Pęczek J. (ed.), 2011. Planning and implementation urban project (in Polish). Akapit-DTP, Gdańsk.

[6] Muñoz Gielen D., van der Krabben E., 2017. Developer Obligations Towards Better Urban Infrastructure. Lincoln Institute of Land Policy, Working Paper.

[7] Melbourne Planning Scheme, 2018. Melbourne, Version incorporating amendments as at $8^{\text {th }}$ February 2018.

[8] Nicholas J. C. et al., 1991. Practitioner's Guide to Development Impact Fees. Chicago, Planners Press.

[9] Ossowicz T., 2017. Developer obligations in public sector in selected countries (in Polish) w: Problemy planistyczne jesień 2017. Zeszyt 02/2017. Stowarzyszenie Urbanistów ZOIU. Wrocław. 69-80.

[10] Ossowicz T., 2018. Developer obligations in public sector in Australia (in Polish). W: Problemy planistyczne - wiosna 2018. Zeszyt 01/2018. Stowarzyszenie Urbanistów ZOIU. Wrocław. 81-90.

[11] Using..., 2015. Using Victoria's planning system, A technical guide to interpretation and administrative procedures under the Planning and Environment Act 1987 and the Planning and Environment Regulations 2005 and their interaction with other related legislation and planning schemes. The State of Victoria. 


\section{Legal acts}

[12] BauGB, 2017, Baugesetzbuch. Ausfertigungsdatum: 23. Juni1960, Fassung der Bekanntmachung vom 3. November 2017 (BGBI. I S. 3634).

[13] Infrastructure Contributions Guidelines, 2016. Infrastructure, The State of Victoria Department of Environment, Water and Planning, 2016.

[14] Municipal Government Act, 2017. Revised Statutes of Alberta 2000, Chapter M-26, Current as of July 1, 2017, Province of Alberta.

[15] Planning and Environment Act, 2017. Planning 1987, No. 45 of 1987, Version No. 124, Version incorporating amendments as at12 April 2017.

[16] RCW, 2018. Revised Code of Washington, version 2018.

[17] Uopizp, 2017. Ustawa z dnia 27 marca 2003 r. o planowaniu i zagospodarowaniu przestrzennym (Dz.U. 2017 poz. 1073 ).

[18] Uogn, 2018. Ustawa z dnia 21 sierpnia 1997 r. o gospodarce nieruchomościami (Dz.U. 2018 poz. 121).

[19] Uor, 2015. Ustawa z dnia 9 października 2015 r. o rewitalizacji (Dz.U. 2015 poz. 1777). 